\title{
Agroforestry systems: integrated land use to store and conserve carbon
}

\author{
Paul Schroeder \\ ManTech Environmental Technology, Inc., U.S. EPA Environmental Research Laboratory, 200 SW 35th St., Corvallis, \\ Oregon 97333, USA
}

\begin{abstract}
Agroforestry is a promising land use practice to maintain or increase agricultural productivity while preserving or improving fertility. From the perspective of climate change and the global carbon cycle, agroforestry practices are attractive for 2 reasons: they directly store carbon in tree components, and they potentially slow deforestation by reducing the need to clear forest land for agriculture. An extensive literature survey was conducted to evaluate the carbon dynamics of agroforestry practices and to assess their potential to store carbon. Data on tree growth and wood production were converted to estimates of carbon storage. Surveyed literature showed that median carbon storage by agroforestry practices was $9 \mathrm{t} \mathrm{Cha}^{-1}$ in semi-arid, $21 \mathrm{t} \mathrm{C} \mathrm{ha-1}$ in sub-humid, $50 \mathrm{t} \mathrm{C}$ $\mathrm{ha}^{-1}$ in humid, and $63 \mathrm{t} \mathrm{Cha}^{-1}$ in temperate ecoregions. The limited survey information available tended to substantiate the concept that implementing agroforestry practices can help reduce deforestation.
\end{abstract}

\section{INTRODUCTION}

The loss of forest cover often entails environmental degradation and a subsequent decline in site productivity. This is true in many parts of the world, but particularly in the tropics where most essential nutrients are contained in aboveground vegetation. After clearing and burning, these nutrients are soon depleted and soil fertility is reduced. A fallow period of 10 or more years is required to restore nutrient capital and fertility (Sabhasri 1978). However, human population growth and the need for agricultural expansion, in conjunction with wood harvesting for fuel and export, have led to increasing deforestation rates. The consequences are not only reduced soil fertility, but also rising prices, erosion, floods, reservoir siltation, and desertification (Allen \& Barnes 1985). Approximately $65 \%$ of the land in the tropical world, which is home to over 630 million people, is susceptible to such degradation (King 1979).

Agroforestry is a promising land use practice to maintain or increase agricultural productivity while preserving or improving fertility. Broadly defined, agroforestry is 'a land use that involves deliberate retention, introduction, or mixture of trees or other woody perennials in crop/animal production fields to benefit from the resultant ecological and economic interactions' (MacDicken \& Vergara 1990). Examples of agroforestry systems include alley cropping, multilayer tree gardens, interplanting of trees on crop land, live hedges, and shelterbelts. A typical agroforestry system allows synergistic interactions between woody and non-woody components to increase. sustain, and diversify total land output (Swaminathan 1987). Important interactions are improved nutrient cycling and retention, moderation of microclimate, and diversification of product outputs.

From the perspective of climate change and the global carbon cycle, agroforestry is attractive for at least 2 reasons. The first is that the tree component fixes and stores carbon from the atmosphere. Because trees are perennial plants they can function as active carbon sinks for periods of many years; trees continue to store carbon until they are cut or die. As much as 500 to 600 million ha of tropical land may be suitable for agroforestry (Houghton et al. 1991), although practices could probably be established on only about 160 million ha by the middle of the next century (Trexler \& Haugen 1991). A second interest in agroforestry is its apparent potential to reduce the need to 
clear new forest land for agriculture by providing an alternative to shifting cultivation (Nair \& Fernandes 1984, Winterbottom \& Hazelwaod 1987, Sanchez et al 1990, Wiersum 1990, Andrasko et al. 1991). Current estimates are that 1 to $2 \mathrm{Gt}$ of carbon are released to the atmosphere annually due to deforestation (Houghton 1991). This is not all the result of clearing for agriculture, but a significant portion is. As many as 300 million people are dependent on some form of shifting cultivation, and they account for about $60 \%$ of all forest clearing (Myers 1991).

The many and varied contributions of the tree component are the key to the ecological benefits of agroforestry (Kang \& Wilson 1987, Young 1989, Ingram 1990). A key structural attribute of agroforestry is muitiple vertical strata that occupy space efficiently and provide a range of growing conditions. The tree canopy provides shade and reduces evaporation from the soil. This shading effect also reduces temperature and provides a more moderate microclimate for crop growth. The tree canopy also provides shelter from wind and protects the soil from the impacts of heavy rain and helps to reduce soil erosion. Leaf litterfall acts as a mulch and reduces both evaporation and surface runoff and erosion. Incorporation of leaves into soil adds organic matter and improves soil quality. Belowground, tree roots penetrate to deeper soil layers than crop roots and bring nutrients to the surface via leaf fall. Nitrogen-fixing agroforestry tree species capture that key nutrient from the atmosphere and make it available to crop plants. The economic benefits of agroforestry derive from diversification of outputs, spreading risk, and, in many cases, actually increasing physical output (MacDicken \& Vergara 1990). These characteristics may also make agroforestry systems more resistant to climate change than monocropping systems

Much has been written about the potential and promise of agroforestry systems. This paper evaluates the carbon dynamics of agroforestry practices and assesses their potential contribution to slowing the increase of atmospheric $\mathrm{CO}_{2}$. The evaluation is based on several criteria: (1) levels of direct carbon storage, (2) levels of carbon conservation resulting from reduced land clearing, (3) crop production, and (4) profitability. The focus of the analysis is primarily on tropical agroforestry practices; where available, information for practices in the temperate zones will be included for comparison.

\section{APPROACH}

Over the past 10 to 15 yr or more, the body of agroforestry knowledge has grown steadily. This information base was exploited by conducting an extensive survey of the published technical literature. Most of this literature focuses on crop production by agroforestry systems. A smaller portion concentrates on production by the tree component, and little or none directly assesses patterns of carbon accumulation. It was necessary, therefore, to use published information on tree growth patterns to estimate carbon storage. Most of this information is reported as stem wood volume which was converted to total aboveground carbon mass. Accumulation of belowground carbon in roots and soil organic matter was not included. Adding belowground carbon would increase estimates even more.

Stem wood volume was first multiplied by wood specific gravity for each species (Chudnoff 1979) to estimate stem biomass. Published information on biomass partitioning between plant parts (e.g. stem branches, leaves) was used to establish ratios to estimate total aboveground biomass. Six examples of biomass partitioning in agroforestry systems, from 4 studies (Ngambeki 1985, Alpizar et al. 1986 , Maghembe et al. 1986, Verma 1987), had a mean ratio of total aboveground biomass to stem wood biomass of 2.15 (range $=1.93$ to 2.40 ). Where tree stocking density was high (>500 trees ha ${ }^{-1}$ ) and the growth cycle or rotation length was relatively long (>10 yr), conditions more similar to a forest plantation situation, a factor of 1.6 was used (Marland 1988, Sedjo 1989, Dixon et al. 1991). The carbon content of biomass was assumed to be $50 \%$ (Brown \& Lugo 1982)

In an agroforestry system, trees are grown for the essential products that they provide; we assume that these trees will be periodically harvested and used. Depending on the end use, much or all of the carbon in harvested material will return to the atmosphere in a relatively short time (Harmon et al. 1990). How then can we assess the long-term carbon storage implications of agroforestry? The relevant parameter in terms of the carbon cycle is the average amount of carbon on-site over one or more growth cycles (Graham et al. 1990, Dixon et al. 1991, Schroeder 1992). The calculation is made by summing the carbon standing crop for each year in the cycle and dividing by the length of the cycle, the simple calculation of a mean. This method was used in this analysis. In sequential or rotational cropping systems, an adjustment would have to be made for the length of the cropping phase when no trees would be present. However, all of the agroforestry practices included in this analysis involved some form of intercropping in which trees and crops are grown simultaneously and trees are always present.

The data were stratified by ecozone using the same broad ecozone classification scheme as Swinkels \& Scherr (1991) in their survey of agroforestry literature. 
Ecozones were defined as follows: humid, precipitation $>1600 \mathrm{~mm} \mathrm{yr}^{-1}$; sub-humid, precipitation $=800$ to $1600 \mathrm{~mm} \mathrm{yr}^{-1}$; semi-arid, precipitation $=400$ to $800 \mathrm{~mm}$ $\mathrm{yr}^{-1}$; temperate, temperate zone climates.

The literature survey also included information on the economics of agroforestry, particularly the present net value (PNV) of agroforestry practices. All reported results were converted to 1990 US dollars. National inflation rates and exchange rates for different years and countries were taken from the International Financial Statistics Tables published by the International Monetary Fund (IMF 1990, 1991). To calculate PNV, future revenue must be discounted to the present (the opposite of compounding a present value to some point in the future). A $12 \%$ discount rate was used to calculate PNV for agroforestry practices in developing countries where poorer farmers are less able to delay consumption and have a high time preference rate (Hoekstra 1985, Hosier 1987). Revenues in the distant future are far less valuable to these farmers who require an income in the present or near future. For temperate regions, a $7.5 \%$ discount rate was most commonly encountered in the literature and was used here also.

\section{DIRECT CARBON STORAGE}

Table 1 shows the median values of carbon storage for the 4 ecozones in the analysis. Preliminary analyses showed that the data were not normally distributed. Conventional statistics like mean and standard error are not appropriate for characterizing such data. A more appropriate measure of central tendency is the median because it is resilient to extreme values and skewed distributions (Devore \& Peck 1986).

The lowest level of carbon storage was $9 \mathrm{t} \mathrm{C} \mathrm{ha}^{-1}$ in the semi-arid ecozones. Carbon storage for the sub-humid ecozones was $21 \mathrm{t} \mathrm{C} \mathrm{ha}^{-1}$, for the humid ecozones it was $50 \mathrm{t} \mathrm{C} \mathrm{ha}^{-1}$, and for the temperate ecozones it was $63 \mathrm{t} \mathrm{C} \mathrm{ha}^{-1}$. Similarity of carbon storage values for the temperate and humid ecozones is explained by length of the growth or cutting cycles and how cycle length affects accumulation of biomass and carbon. As expected, growth rates for humid tropical ecozones were over twice those for the temperate ecozones, $10 \mathrm{t} \mathrm{C} \mathrm{ha}^{-1} \mathrm{yr}^{-1}$ versus about $4 \mathrm{t} \mathrm{C} \mathrm{ha-1} \mathrm{yr}^{-1}$. For the examples of agroforestry surveyed, however, the average cutting cycle was 6 times longer in the temperate than humid ecozone, 30 yr versus 5 yr. As a result, biomass accumulation is restricted in the humid ecozones. The relationship between carbon storage, growth rate, and cycle length is nonlinear. As length of the cutting cycle increases, the growth rate required to maintain a given level of carbon storage decreases at a decreasing rate. For longer cutting cycles, a given change in growth rate causes relatively greater change in carbon storage than for short cutting cycles.

The net effects on carbon storage of implementing agroforestry practices depend on the carbon content of the land uses that they replace. At least 3 land type categories are top candidates for agroforestry: currently degraded and non-productive land, lands that are in more or less permanent agriculture or pasture that could be supplemented with tree planting, and lands under short fallow agriculture. The first 2 categories have depleted aboveground carbon pools; therefore the net carbon increase should be approximately as much as results shown in Table 1.

However, the third land use category, short fallows of less than $5 \mathrm{yr}$, represents a substantial carbon storage pool. Five estimates of regrowth of 5 to 6 yr old fallows in the humid and sub-humid tropics (Toky \& Ramakrishnan 1983, Uhl 1987, Brown \& Lugo 1990) were used to calculate mean carbon standing stock. Results ranged from 7 to $12 t \mathrm{C} \mathrm{ha}^{-1}$ with a mean of $10 \mathrm{t} \mathrm{C} \mathrm{ha}^{-1}$. Subtracting this mean from the results in Table 1 results in net carbon storage of 11 and $40 \mathrm{tC} \mathrm{ha}{ }^{-1}$ for sub-humid and humid ecozones respectively. Data in Brown \& Lugo (1990) were also used to estimate a mean carbon standing stock of a 4 yr old dry tropical secondary forest of about $5 \mathrm{t} \mathrm{C} \mathrm{ha-1.} \mathrm{Subtracting} \mathrm{this} \mathrm{amount} \mathrm{from} \mathrm{the}$ estimate in Table 1 results in net carbon storage of about $4 \mathrm{t} \mathrm{C} \mathrm{ha}^{-1}$ for semi-arid ecozones.
Table 1. Median values for aboveground carbon storage, annual growth rate, and rotation length for agroforestry practices in different ecozones. $\mathrm{n}:=$ number of studies located in the literature

\begin{tabular}{|lcccc|}
\hline Ecozone & $\begin{array}{c}\text { Carbon storage } \\
(\mathrm{t} \mathrm{C} \mathrm{ha-1})\end{array}$ & $\begin{array}{c}\text { Growth rate } \\
\left(\mathrm{t} \mathrm{C} \mathrm{ha-1} \mathrm{yr}^{-1}\right)\end{array}$ & $\begin{array}{c}\text { Cutting cycle } \\
\text { (yr) }\end{array}$ & $\mathrm{n}$ \\
\hline Semi-arid & 9 & 2.6 & 5 & 15 \\
Sub-humid & 21 & 6.1 & 8 & 15 \\
Humid & 50 & 10.0 & 5 & 8 \\
Temperate & 63 & 3.9 & 30 & 4 \\
\hline
\end{tabular}

\section{CARBON CONSERVATION}

If agroforestry is developed as a sustainable, permanent agricultural practice, then 2 expected results should be reduced clearing of mature forest to create new agricultural land and extended regrowth of fallows that no longer need to be recleared on short cycles. Brown \& Lugo (1984) reported that the average above- 
ground biomass for humid tropical forests, including both disturbed and undisturbed, was about $140 \mathrm{tha}^{-1}$. If this biomass is composed of about $50 \%$ carbon, then average carbon density is $70 \mathrm{tC} \mathrm{ha}^{-1}$. In another study. Brown \& Lugo (1990) cited maximum biomass accumulation for secondary tropical forests of $200 \mathrm{tha}^{-1}$, or about $100 \mathrm{t} \mathrm{C} \mathrm{ha}^{-1}$, at age $80 \mathrm{yr}$. A chronosequence study in Venezuela and Colombia provides additional information about the rate of biomass accumulation in secondary tropical forests. Saldarriaga (1985) found that by age 40 yr forest fallows had accumulated about $50 \%$ of the biomass of mature forest stands. Putting this information together, we can make some first approximation estimates of carbon conserved or 'secondarily accumulated' (i.e. by fallows) by establishment of agroforestry practices. Each hectare of mature forest conserved as a result of agroforestry should contain, on average, 70 to $100 \mathrm{t} \mathrm{C}$. Forest fallows that are allowed to regrow should accumulate 35 to $50 \mathrm{tC} \mathrm{ha}^{-1}$ over the first 40 yr period. These levels of carbon storage and conservation would be in addition to carbon stored directly by the tree component of agroforestry systems.

Published literature contains very few reports on the effects of agroforestry on forest clearing. Although several publications suggest the potential of agroforestry to have a beneficial influence on land clearing practices, this survey found only 3 examples where a land clearing effect was quantified or where information was presented that allows an estimation. Trexler \& Haugen (1992) state that the ratio of cleared area foregone to agroforestry implemented could be $7: 1$. In a 1 ha experimental study, Sanchez \& Benites (1987) demonstrated a low-input cropping system that produced the agricultural equivalent of 14 ha of slash and burn practices, implying a 14:1 ratio. Finally information reported by Morningstar (1989) implies an 11.5:1 ratio for implementation of agroforestry in Sarawak.

This limited information on land clearing does not allow us to draw any conclusions on how much carbon could be conserved as a result of implementing agroforestry. However, it gives a preliminary indication that the outcome is potentially significant. If the ratio of clearing foregone to agroforestry implemented were as great as $5: 1$, the amount of carbon conserved in mature forest would be 350 to $500 \mathrm{t} C$ $\mathrm{ha}^{-1}$ (based on a carbon content of 70 to $100 \mathrm{t} \mathrm{C}$ $\mathrm{ha}^{-1}$ ). For secondary forest, 5 ha of conserved forest represents 175 to $250 \mathrm{t} \mathrm{C}^{-1} \mathrm{~h}^{-1}$ (based on a carbon content of 35 to $50 \mathrm{t} \mathrm{C} \mathrm{ha}^{-1}$ ). All of these values are considerably higher than those for carbon stored directly by agroforestry practices. They are also higher than the estimated carbon storage potential of tree plantations (Dixon et al. 1991, Schroeder 1992). These first approximations are promising, but clearly there is a need for additional information on this topic. More information is needed from actual agroforestry programs to determine what levels of forest clearing offset are realistically attainable.

\section{CROP PRODUCTION}

Current interest in agroforestry arises from its apparent potential to increase agricultural productivity. In many cases this potential has been realized. The effect whereby intercropping 2 or more species increases yield has been called facilitation (Vandermeer 1989) or complementarity (Filius 1988). It results when an organism affects the environment in a positive way with respect to other organisms. Examples exist in the literature where, at least in experimental applications, agroforestry practices have been significantly more productive than conventional agriculture. For example, in Nigeria, intercropping with Leucaena trees increased maize yield by $68 \%$ (Ngambeki 1985). Pasture grass in Australia was more productive when grown in conjunction with trees (Wilson et al. 1990). Tea yields in China were $30 \%$ higher under trees than without trees (Yu et al. 1991). MacDicken \& Vergara (1990) reviewed 11 examples of crop yield improvements of 14 to $367 \%$ under coconut, with a mean increase of $89 \%$. They also cite 5 examples of crop yield increases under Acacia albida that average $78 \%$. These yield improvements presumably occurred because of microenvironmental improvements caused by the trees (e.g. shading or nitrogen fixation).

Other results, however, suggest that agroforestry practices may be less effective than monocropping in some circumstances. Competition occurs when an organism affects the environment in a negative way with respect to other organisms (Vandermeer 1989). The primary environmental resources for which plants compete are light, water, and soil nutrients (Trenbath 1974); competition may be most intense where these factors are most limiting. For example, Kang et al. (1989) found that the agroforestry practice of alley cropping is not as promising in semi-arid as humid zones because of greater competition for moisture between crops and trees. Nair (1990) also cites 9 examples from India, Nigeria, and Kenya where crop yields were lower for agroforestry than for monocropping. Differences in the morphology and physiology of mixture constituents can cause their individual members to experience different microenvironments and resource availabilities than those grown in monoculture (Trenbath 1974). The end result may be reduced production in the agroforestry system. 


\section{PROFITABILITY}

The present net values reported in the literature were extremely variable and it was not possible to make any quantitative generalizations for the different ecozones or practices. PNV varied by 2 orders of magnitude from a low of US $\$ 54 \mathrm{ha}^{-1}$ to a high of over US $\$ 6000 \mathrm{ha}^{-1}$. The median of all values $(\mathrm{n}=34)$ was about US $\$ 1200 \mathrm{ha}^{-1}$. Trexler \& Haugen (1992) reached a similar conclusion in an analysis of forestry projects. The economics of forestry projects were so dependent on country- and project-specific variables that no general conclusions could be justified. The term agroforestry encompasses a wide variety of practices in a wide variety of circumstances and countries. Economic attractiveness is affected by the type and level of product outputs, existence and access to markets, transportation infrastructure and costs, and alternative employment opportunities.

Numerous individual examples in the literature illustrate situations where agroforestry is more profitable than alternative forms of agriculture. In the temperate zone, several studies have shown that growing trees in conjunction with livestock grazing is more profitable than grazing alone (e.g. Arthur-Worsop 1984, Doyle et al. 1986, Anderson et al. 1988). For a study in China, He (1991) reported that intercropping with trees in the warm temperate zone was 136 to $158 \%$ more profitable than growing wheat or other crops singly. Similar instances exist in the tropics. In India, intercropping was more profitable than either tree or crop monocultures (Srivastava \& Pant 1979, Shekhawat et al. 1988). Ngambeki (1985) related the same result for Nigeria where the reduced nitrogen requirement and increased maize output made intercropping more economically attractive than monocropping. In Tanzania, gross revenues from agroforestry were over 7 times greater than those from conventional maize/bean agriculture (Cook \& Grant 1989).

The only conclusion reached from a survey of economic information is that agroforestry can be economically profitable in a wide variety of circumstances. The biological significance is that profitable agroforestry systems also store carbon at no additional cost. However, agroforestry practices may not always be the most economically attractive option, as is discussed below.

We should not be surprised that agroforestry systems can produce positive PNVs. If such was not the case, interest in agroforestry would have waned long ago. Positive PNV alone, however, may not be a sufficient incentive for smallholders to adopt agroforestry (Hosier 1987, 1989). Agroforestry is an approach for increasing the intensity of land use by applying labor. Although labor is generally assumed to be plentiful and, therefore, of low value, its value is not zero. Farmers can apply their labor on the farm to various agricultural practices, or sell it on the market by accepting off-farm employment. Theoretically, farmers will choose the alternative that is most profitable to them and their families. To be induced to choose agroforestry, farmers must perceive that they will be adequately compensated for their labor (Hosier 1989). Not only must benefits exceed costs, but they must exceed costs by a greater margin than other options.

Despite its promise and its environmental desirability, agroforestry may not always be the most desirable alternative; it depends on specific situations (environmental, economic, and social) and other available options. For example, an analysis in Nigeria found that where access to new forest land is essentially costless (i.e. low population pressure and abundant forest), traditional bush fallow agriculture with a long fallow period is advantageous, but where there is heavy population pressure on land resources, an alley cropping agroforestry system was the most desirable option (Ehui et al. 1990). There may also be instances where farmers have too little land, technical knowledge, or labor to adopt agroforestry. In such tightly constrained circumstances, agroforestry may place too much of a burden on these limited resources (Hosier 1989). In general, however, the prospects for the implementation and use of agroforestry practices should be good. It is a very adaptable technology that can take many forms and fulfill the requirements of many different situations

\section{CONCLUSIONS}

The preceding discussion highlighted some of the promising aspects of agroforestry practices from the perspectives of both farmers and those concerned about climate change. From the farmers' perspective, agroforestry can be a way to increase crop yields from their land while increasing the diversity of products grown. A secondary outcome is the creation of a carbon sink that removes carbon from the atmosphere and stores it in the terrestrial biota. Successful agroforestry is a sustainable and permanent type of agriculture that does not require repeated land clearing. As a result, potentially large amounts of carbon could be conserved in the terrestrial biota that would otherwise be released to the atmosphere. Whether this potential is realized or not depends on non-biological factors such as government policies and future population trends. In many instances agroforestry is more profitable than alternative practices. Where this is true, the cost of storing and conserving the associated car- 
bon is essentially zero. This would rank agroforestry with other mitigation strategies, such as increased building energy efficiency and vehicle efficiency, that yield net benefits (NAS 1991). The profitability of agroforestry is very important for its widespread adoption; short-term cash profits are more attractive to farmers than are long-term environmental benefits (Hosier 1989).

It is risky to attempt to estimate the total amount of carbon that could be stored by agroforestry because current estimates of land available for conversion to agroforestry are uncertain. The most realistic estimate may be the 160 million ha in the tropics derived by Trexler \& Haugen (1991). They included economic, social, and political factors that affect land availability in addition to its biological suitability. Their analysis distributed the total 160 million ha roughly equally between the 3 tropical zones (tropical Africa, Asia and America), but it did not distinguish between ecozones. A very rough approximation of the potential range for total carbon storage is possible by multiplying their total estimate of available land by each of the carbon storage estimates in Table 1 . The result is between ca 1.5 billion $\mathrm{t} C$ and 8.0 billion $\mathrm{t} C$. Improved and refined estimates of land availability are required to reduce the uncertainties in these values.

Estimates of the total carbon conservation potential of agroforestry resulting from reduced deforestation are unavailable. Limited evidence currently available indicates that the potential is real but impossible to quantify. Additional efforts should be directed to answering this question because reducing deforestation might have a larger impact on the global carbon cycle than direct carbon storage by agroforestry practices.

Acknowledgements. I am particularly grateful to Greg Baumgardner, ManTech Environmental Technology, Inc., for his assistance in designing and implementing the database that was used to organize the results of the literature survey. Without his assistance completing this project would have been a much more tedious and time consuming undertaking. I also thank Barb Hagler, Computer Services Corporation, for her invaluable help in locating and obtaining virtually all of the reference material that went into this analysis. Richard Olson and Steve Radosevich reviewed an earlier draft of this paper and provided valuable suggestions. Three anonymous reviewers also provided many helpful comments that improved the quality of the paper. The research described in this article was funded by the U.S. Environmental Protection Agency. This document was prepared at the EPA Environmental Research Laboratory in Corvallis, Oregon, through contract number 68-C80006 to ManTech Environmental Technology, Inc. It has been subjected to the Agency's peer and adminstrative review and approved for publication. Mention of trade names or commercial products does not constitute endorsement or recommendation for use.

\section{LITERATURE CITED}

Allen, J. C., Barnes, D. F. (1985). The causes of deforestation in developing countries. Ann. Ass. A.m. Geographers 75(2): $163-184$

Alpizar, L., Fassbender, H. W., Heuveldop, J., Folster, H., Enriquez, G. (1986). Modelling agroforestry systems of cacao (Theobroma cacao) with laurel (Cordia alliodora) and poro (Erythrina poeppigiana) in Costa Rica. I. Inventory of organic matter and nutrients. Agrofor. Syst. 4: $175-189$

Anderson, G. W., Moore, R. W., Jenkins, P. J. (1988). The integration of pasture, livestock and widely spaced pine in South West Western Australia. Agrofor. Syst. 6: 195-211

Andrasko, K., Heaton, K., Winnett, S. (1991). Estimating the costs of forest sector management options: overview of site, national, and global analyses. In: Howlett, D., Sargent, C. (eds.) Proceedings of a technical workshop to explore options for global forest management. April 24-30, Bangkok, Thailand. International Institute for Environment and Development, London, p. 216-233

Arthur-Worsop, M. J. (1984). An economic evaluation of agroforestry: the national viewpoint. In: Proceedings of a technical workshop on agroforestry. Ministry of Agriculture and Fisheries, Wellington, New Zealand, pages 61-70

Brown, S., Lugo, A. E. (1982). The storage and production of organic matter in tropical forests and their role in the global carbon cycle. Biotropica 14: 161-187

Brown, S., Lugo, A. E. (1984). Biomass of tropical forests: a new estimate based on forest volumes. Science 223: $1290-1293$

Brown, S., Lugo, A. E. (1990). Tropical secondary forests. J. trop. Ecol. 6: 1-32

Chudnoff, M. (1979). Tropical timbers of the world. USDA Forest Service, Forest Products Laboratory, Madison, WI

Cook, C. C., Grant, M. (1989). Agroforestry in sub-Saharan Africa: a farmer's perspective. World Bank Technical Paper No. 112. The World Bank, Washington, DC

Devore, J., Peck, R. (1986). Statistics: the exploration and analysis of data. West Publishing, St. Paul, MN

Dixon, R. K., Schroeder, P. E., Winjum, J. K. (1991). Assessment of promising forest management practices and technologies for enhancing the conservation and sequestration of atmospheric carbon and their costs at the site level. Report EPA/600/3091/067. US Environmental Protection Agency, Corvallis, OR

Doyle, C. J., Evans, J., Rossiter, J. (1986). Agroforestry: an economic appraisal of the benefits of intercropping trees with grassland in lowland Britain. Agricult. Syst. 21 : $1-32$

Ehui, S. K., Kang, B. T., Spencer, D. S. C. (1990). Economic analysis of soil erosion effects in alley cropping, no-till and bush fallow systems in southwestern Nigeria. Agricult. Syst. 34: $349-368$

Filius, A. M. (1988). Economic aspects of agroforestry. In: Wiersum, K. F. (ed.) Viewpoints on agroforestry, 2nd edn. Wageningen Agricultural University, Wageningen, p. $169-188$

Graham, R. L., Perlack, R. D., Prasad, A. M. G., Ranney, J. W., Waddle, D. B. (1990). Greenhouse gas emissions in subsaharan Africa. Report ORNL-6640, U.S. Dept of Energy, Oak Ridge National Laboratory, Oak Ridge

Harmon, M. E., Ferrell, W. W., Franklin, J. F. (1990). Effects on carbon storage of conversion of old-growth forests to young forests. Science 247: 699-702

He, Q. (1991). Economic evaluation of intercropping with Paulownia - optimisation and choice of intercropping 
models. In: Zhu, Z., Cai, M., Wang, S., Jiang, Y. (eds.) Agroforestry systems in China. Chinese Academy of Forestry, Beijing, p. 77-88

Hoekstra, D. A. (1985). Choosing the discount rate for analyzing agroforestry systems/technologies from a private economic viewpoint. For. Ecol. Mgmt 10: 177-183

Hosier, R. H. (1987). The economics of agroforestry: obstacles and incentives to ecodevelopment. Perspectives in agroforestry, Technical Report No. 2, Washington State University, Pullman, WA

Hosier, R. H. (1989). The economics of smallholder agroforestry: two case studies. World Dev. 17(11): 1827-1839

Houghton, R. A. (1991). Tropical deforestation and atmospheric carbon dioxide. Clim. Change 19: 99-118

Houghton, R. A., Unruh, J., Lefebvre, P. A. (1991). Current land use in the tropics and its potential for sequestering carbon. In: Howlett, D., Sargent, C. (eds.) Proceedings of a technical workshop to explore options for global forest management. April 24-30, Bangkok, Thailand. International Institute for Environment and Development, London, p. $297-310$

Ingram, J. (1990). The role of trees in maintaining and improving soil productivity: a review of the literature. In: Prinsley, R. T. (ed.) Agroforestry for sustainable production. Commonwealth Science Council, London, p. 243-304

IMF (International Monetary Fund) (1990). International Financial Statistics Yearbook, Vol. XLIII. IMF, Washington, DC

IMF (International Monetary Fund) (1991). International Financial Statistics Yearbook, Vol. XLIV. IMF, Washington, DC

Kang, B. T., Reynolds, L., Atta-Krah, A. N. (1989). Alley farming. Adv. Agron. 43: 315-359

Kang, B. T., Wilson, G. F. (1987). The development of alley cropping as a promising agroforestry technology. In: Steppler, H. A., Nair, P. K. R. (eds.) Agroforestry: a decade of development. International Council for Research in Agroforestry, Nairobi, p. 227-244

King, K. F. S. (1979). Agroforestry and the utilisation of fragile ecosystems. For. Ecol. Mgmt 1: 161-168

MacDicken, K.G., Vergara, N.T. (1990). Agroforestry: classification and management. John Wiley and Sons, New York

Maghembe, J. A., Kaoneka, A. R. S., Lulandala, L. L. L. (1986). Intercropping, weeding and spacing effects on growth and nutrient content of Leucaena leucocephala at Morogoro, Tanzania. For. Ecol. Mgmt 16: 269-279

Marland, G. (1988). The prospect of solving the $\mathrm{CO}_{2}$ problem through global reforestation. Report DOE/NBB-0082, U.S. Dept of Energy, Office of Energy Research, Washington, DC

Morningstar, O. R. (1989). Reforestation and agroforestry community forestry within the permanent forest estate in Sarawak. In: Nuruddin, A. S., Awang, K., Emby, Z. (eds.) Social forestry in Malaysia. Universiti Pertanian Malaysia, Selangor, p. 41-67

Myers, N. (1991). Tropical forests: present status and future outlook. Clim. Change 19: 3-32

Nair, P. K. R. (1990). The prospects for agroforestry in the tropics. The World Bank Technical Paper No. 131. The World Bank, Washington, DC

Nair, P. K. R., Fernandes, E. (1984). Agroforestry as an alternative to shifting cultivation. In: Improved production systems as an alternative to shifting cultivation. FAO Soils Bulletin No. 53. FAO, Rome, p. 169-182

NAS (National Academy of Sciences) (1991). Policy implications of greenhouse warming. National Academy Press, Washington, DC
Ngambeki, D. S. (1985). Economic evaluation of alley cropping Leucaena with maize-maize and maize-cowpea in southern Nigeria. Agricult. Syst. 17: 243-258

Sabhasri, S. (1978). Effects of forest fallow cultivation on forest production and soil. In: Kunstadter, P., Chapman, D. Sabhasri, S. (eds.) Farmers in the forest: economic development and marginal agriculture in northern Thailand University Press of Hawaii, Honolulu, p. 160-184

Saldarriaga, J. G. (1985). Forest succession in the Upper Rro Negro of Colombia and Venezuela. Ph.D. thesis. University of Tennessee, Knoxville

Sanchez, P. A., Benites, J. R. (1987). Low-input cropping for acid soils of the humid tropics. Science 238: 1521-1527

Sanchez, P. A., Palm, C. A., Smyth, T. J. (1990). Approaches to mitigate tropical deforestation by sustainable soil management practices. In: Scharpenseel, H. W., Schomaker, M., Ayoub, A. (eds.) Soils on a warmer earth: effects of expected climate change on soil processes, with emphasis on the tropics and sub-tropics. Elsevier, Amsterdam, p. 211-220

Schroeder, P. E. (1992). Carbon storage potential of short rotation tropical tree plantations. For. Ecol. Mgmt 50: 31-41

Sedjo, R. A. (1989). Forests to offset the greenhouse effect. J. For. $87(7): 12-15$

Shekhawat, J. S., Sen, N. L., Somani, L. L. (1988). Evaluation of agroforestry systems under semi-arid conditions of Rajastan. Indian For 114(2): 98-101

Srivastava, B. P., Pant, M. M. (1979). Social forestry on a costbenefit analysis framework. Indian For. 105(1): 2-35

Swaminathan, M. S. (1987). The promise of agroforestry for ecological and nutritional security. In: Steppler, H. A., Nair, P. K. R. (eds.) Agroforestry: a decade of development. International Council for Research in Agroforestry. Nairobi, p. $25-42$

Swinkels, R. A., Scherr, S. J. (1991). Economic analysis of agroforestry technologies: an annotated bibliography. International Council for Research in Agroforestry, Nairobi

Toky, O. P., Ramakrishnan, P. S. (1983). Secondary succession following slash and burn agriculture in northeastern India: I. Biomass, litterfall, and productivity. J. Ecol. 71: $735-745$

Trenbath, B. R. (1974). Biomass productivity of mixtures. Adv. Agron. 26: 177-210

Trexler, M. C., Haugen, C. (1991). Using tropical forestry to mitigate global warming: a preliminary carbon assessment. Draft final report to the U.S. Environmental Protection Agency, Washington, DC

Trexler, M. C., Haugen, C. (1992). Keeping it green: a preliminary physical, social, and institutional assessment of carbon forestry opportunities in the tropics. Seminar presented at US Environmental Protection Agency Research Laboratory, Corvallis, OR, April 1, 1992

Uhl, C. (1987). Factors controlling succession following slash and burn agriculture in Amazonia. J. Ecol. 75: 377-407

Vandermeer, J. (1989). The ecology of intercropping. Cambridge University Press, Cambridge

Verma, D. P. S. (1987). The flow of benefits from the Dhanori village woodlot scheme. Int. Tree Crops J. 4: 89-108

Wiersum, K. F. (1990). Planning agroforestry for sustainable land use. In: Budd, W. W., Duchart, I., Hardesty, L. H., Steiner, F. (eds.) Planning for agroforestry. Elsevier Science Publishers, Amsterdam, p. 18-32

Wilson, J. R., Hill, K., Cameron, D. M., Shelton, H. M. (1990). The growth of Paspalum notatum under the shade of a Eucalyptus grandis plantation canopy or in full sun. Trop. Grassl. 24: 24-28 
Winterbottom, R., Hazelwood, P. T. (1987). Agroforestry and sustainable development: making the connection. Ambio 16(2-3): $100-110$

Young, A. (1989). Agroforestry for soil conservation. CAB International, Wallingford, UK

Yu, S., Wang, S., Wei, P., Zhu, Z., Lu, X., Fang, Y. (1991).
A study on Paulownia-tea intercropping system: Microclimate modification and economic benefits. In: Zhu, Z., Cai, M., Wang, S., Jiang, Y. (eds.) Agroforestry systems in China. The Chinese Academy of Forestry, People's Republic of China and International Development Research Centre, Canada, p. 150-161 